\title{
Macrophage activation syndrome at the onset of glucocorticoid-resistant systemic lupus erythematosus: a case report
}

\author{
DELIA TULBĂ $\breve{1}^{1}$, MARIUS BALEA², CRISTIAN BĂICUŞS \\ ${ }^{1}$ Internal Medicine Department, "Colentina” Clinical Hospital, Bucharest, Romania \\ ${ }^{2}$ Hematology Department, "Colentina" Clinical Hospital, Bucharest, Romania \\ 3"Carol Davila" University of Medicine and Pharmacy, Bucharest, Romania
}

\begin{abstract}
Introduction. Macrophage activation syndrome (MAS) is a life-threatening hyperinflammatory state mediated by uncontrolled cytokine storm and haemophagocytosis. Although rarely reported, MAS might occur in systemic lupus erythematosus (SLE), notably as an inaugural manifestation. Glucocorticoids (GCs) are the cornerstone of SLE therapy. However, in some cases high doses of GCs are required to achieve remission (i.e. glucocorticoid-resistance), leading to significant side effects.

Case report. A 28-year-old Romani male was admitted to our hospital for polyarthralgia, polyserositis and fatigability. The patient had high-grade fever, jaundice and generalized lymphadenopathy. Laboratory tests revealed severe mixed hemolytic autoimmune anemia, leukopenia, hepatocytolysis, coagulation abnormalities, hypertriglyceridemia, biological inflammatory syndrome, hyperferritinemia and persistent proteinuria of nephritic pattern. Imaging studies showed pleuropericardial effusion, hepatosplenomegaly and polysynovitis. Additional blood tests revealed hypocomplementemia and positive ANA, anti-dsDNA and anti-Sm antibodies. Haemophagocytosis was not identified either on bone marrow or axillary lymph node biopsy specimens. However, SLEassociated MAS seemed to fit this set-up. High-dose corticotherapy (6.5 g methylprednisolone followed by prednisone, $1.5 \mathrm{mg} / \mathrm{kg} /$ day after discharge) and intravenous cyclophosphamide were necessary to induce and sustain remission.

Conclusion. MAS is a potentially severe manifestation that should be considered at SLE onset whenever high fever and elevated serum levels of aspartate aminotransferase, lactate dehydrogenase, C-reactive protein, ferritin and procalcitonin are noted. Early diagnosis and prompt treatment lead to remission in two thirds of cases.

Glucocorticoid-resistance leads to the use of high-dose corticotherapy or immunosuppressive agents that could elicit serious side effects. New insights into the molecular mechanisms of glucocorticoid-resistance are needed in order to conceive more adequate GC-therapies.
\end{abstract}

Key words: macrophage activation syndrome, systemic lupus erythematosus, hyperferritinemia, glucocorticoid-resistance, high-dose corticotherapy.

\section{INTRODUCTION}

Systemic lupus erythematosus (SLE) is a systemic chronic autoimmune disease that often raises diagnosis difficulties because of its heterogeneous presentation and lack of pathognomonic features. Moreover, as with the majority of rheumatic diseases, in the absence of diagnostic criteria, SLE diagnosis is based mainly on clinical judgement, after exclusion of alternative diagnoses [1]. Classification criteria are often used for diagnostic approach although they were designed for clinical research [1].

The invariably negative course of SLE has radically changed since the discovery of glucocorticoids (GCs) in the mid-twentieth century.
Significant side effects have emerged from corticotherapy, especially with long-term use of high doses, leading to considerable efforts to applying the minimal effective dose of GCs [2]. However, considering the variable SLE clinical course and treatment response, a consensus regarding the appropriate dosages of GCs still lacks at the moment [2]. Moreover, some patients do not respond sufficiently to usual corticotherapy doses (i.e., glucocorticoid-resistance), leading to prescription of higher doses of GCs or additional immunosuppressive therapies [2].

In this report, we present a case of SLE requiring high doses of GCs. We will discuss the main differential diagnoses emphasizing the difficulty of diagnosing lupus in some cases, as well as the mechanisms of GC-resistance. 


\section{CASE REPORT}

A 28-year-old man of Romani ethnicity complaining of polyarthralgia and fatigability was transferred to our hospital from a pneumology clinic where he had been admitted two weeks earlier for left upper lobe pneumonia with negative TB status. Pleuropericarditis and severe hemolytic autoimmune anemia with positive cold agglutinins had also been noted.

On admission to our clinic, the patient had high-grade fever, jaundice and bilateral cervical and axillary lymphadenopathy. Blood tests revealed bicytopenia (anemia - $7 \mathrm{~g} / \mathrm{dL}$, leucopenia - 3200/ $\mu \mathrm{L}$ with lymphopenia - $820 / \mu \mathrm{L}$ ), hemolytic stigmata, positive direct Coombs test for IgG, IgM, C3c and $\mathrm{C} 3 \mathrm{~d}$, moderate hepatic cytolysis and cholestasis, D-dimer level 40 times the upper limit of normal, an INR of 1.22, biological inflammatory syndrome, transferrin saturation of $43.5 \%$, hyperferritinemia $(4900 \mathrm{ng} / \mathrm{mL})$ and hypertriglyceridemia. The 24-hour proteinuria by spot urine protein/creatinine ratio was $420 \mathrm{mg}$. The thoraco-abdominal CT scan showed pleuropericardial effusion, hepatosplenomegaly and paraaortic lymphadenopathy. Synovitis involving left wrist and right elbow was identified on articular ultrasonography. Additional blood tests revealed $\mathrm{C} 3$ and $\mathrm{C} 4$ hypocomplementemia and high titres of ANA, anti-dsDNA and anti-Sm antibodies. Blood, sputum and urine cultures as well as antibodies to HIV, hepatitis viruses and Mycoplasma pneumoniae were negative. Bone marrow aspiration and biopsy were performed, indicating erythroid hyperplasia. An axillary lymph node biopsy specimen was obtained: the first histopathological examination inclined towards T-cell non-Hodgkin lymphoma yet advised seeking a second expert opinion which diagnosed chronic reactive lymphadenitis. In the light of these results, the diagnosis of SLE-associated macrophage activation syndrome (MAS) seemed appropriate.

On admission, given the illness severity (SIRS criteria) and the high suspicion of SLE, methylprednisolone pulse therapy $1 \mathrm{~g} /$ day was initiated. After three days, the response was equivocal: worsening anemia $(5.7 \mathrm{~g} / \mathrm{dL})$, persistence of high-grade fever and arthralgias and improving biological inflammatory syndrome as well as hyperferritinemia $(3100 \mathrm{ng} / \mathrm{mL})$. Corticotherapy up to a total dose of $6.5 \mathrm{~g}, 500 \mathrm{mg} / \mathrm{m}^{2}$ pulse intravenous cyclophosphamide (the longer, higher dose $\mathrm{NIH}$ regimen) and red blood cell transfusion were administered, leading to clinical improvement.
$1 \mathrm{mg} / \mathrm{kg} /$ day prednisone-equivalent oral corticotherapy was planned on discharge, but it was increased to $1.5 \mathrm{mg} / \mathrm{kg} /$ day because of recurring fever and polyarthralgia. Afterwards, hydroxychloroquine, oral maintenance corticotherapy tapered to a dose of $1.35 \mathrm{mg} / \mathrm{kg} /$ day and monthly intravenous pulses of cyclophosphamide $\left(750 \mathrm{mg} / \mathrm{m}^{2}\right)$ were used to achieve long-term remission.

\section{DISCUSSION}

Our patient fulfilled eight of the SLICC Classification Criteria for SLE, namely arthritis, serositis, hemolytic anemia, leukopenia/lymphopenia, low complement, positive ANA, anti-dsDNA and anti-Sm antibodies. Since SLICC Classification Criteria have a specificity of only $84 \%$ [3], we ran additional tests to exclude alternative diagnoses.

Although lymphadenopathy occurs frequently in active SLE, a lymph node biopsy is sometimes useful for diagnosis, especially in the occurrence of atypical SLE features. Considering this, cholestatic hepatitis with hepatomegaly as well as severe mixed autoimmune hemolytic anemia requiring multiple therapy lines [4] guided us towards a lymphoproliferative disorder that was not ultimately confirmed.

Hyperferritinemia in the absence of both iron overload and significant hepatocytolysis is likely reactive, particularly in the setting of inflammatory biological syndrome [5]. Moreover, serum ferritin levels above $561 \mathrm{ng} / \mathrm{mL}$ in patients with fever of unknown origin might be linked to a high probability of non-infectious inflammatory or hematologic diseases [6]. Adult-onset Still's disease (AOSD) and haemophagocytic lymphohistiocytosis (HLH) are the most representative diseases that correlate with significantly elevated serum ferritin levels. Our patient fulfilled the five required Yamaguchi's classification criteria for AOSD, but exclusion criteria (i.e., other rheumatic diseases) were not satisfied. A secondary form of HLH, namely SLEassociated MAS, seemed plausible. Although a rare complication, MAS might be an inaugural presentation of SLE [7]. Our patient met four out of the five required diagnostic criteria for HLH (HLH2004 trial), but haemophagocytosis could not be identified in either bone marrow or lymph node. However, these criteria were validated only for children and the failure to display haemophagocytosis does not exclude diagnosis, especially at disease onset [8]. Haemophagocytosis also lacks specificity as histiocytic infiltration in bone 
marrow is often found in severely ill patients [8]. Unlike SLE flares, MAS frequently associates significant increases in lactate dehydrogenase, ferritin, C-reactive protein and procalcitonin serum levels [7], as in our case. Of these laboratory findings, hyperferritinemia above $500 \mathrm{ng} / \mathrm{mL}$ appears to be the best indicator of MAS [7]. In this setting, a diagnosis of SLE-associated MAS seemed appropriate. Clinical improvement following high doses of GCs and cyclophosphamide is consistent with previously reported data, indicating a good prognosis (5\% mortality), as opposed to other secondary HLH (41\% mortality) [7]. Leukopenia and hyperferritinemia in patients with SLE-associated MAS might predict a good response to cyclophosphamide [9], as happened in our case.

By targeting all the cells resulting from the overactivation of both the adaptive and innate immune system, GCs represent the main therapeutic strategy in SLE [2]. Why some patients require high doses of GCs to maintain disease control is still a matter of debate, but several causal factors and molecular mechanisms have been identified. Genetic susceptibility, cellular microenvironment changes, hypoxia and oxidative stress are most quoted [10]. P-glycoprotein (P-gp), a membrane- associated efflux pump that transports several drugs out of the cell (including GCs), is significantly elevated in peripheral lymphocytes of SLE patients compared to healthy controls. Since a positive correlation between disease activity and P-gp levels was proved [11], P-gp overexpression becomes one of the responsible factors for poor response to steroid therapy in lupus patients. Other molecular mechanisms of GC-resistance involve alterations in the signaling pathways of proinflammatory cytokines. They induce defective interaction between GC and GC receptor (GCR) at different levels, particularly reduced GC binding to GCR, GCR decreased expression, impaired nuclear translocation and altered posttranslational modifications, as well as altered cofactor activity [12].

GC-resistance is a serious problem in clinical practice as it requires either high-dose GCs or additional immunosuppressive therapies that could elicit serious side effects. Sustained efforts should be made to achieve better knowledge of the molecular mechanisms of GC-resistance in order to develop strategies to reverse them.

Declaration of interest. The authors declare that there are no conflicts of interest.

Introducere. Sindromul de activare macrofagică (SAM) este un status hiperinflamator cu potenţial letal mediat de hiperexpresie citokinică şi hemofagocitoză. Deşi rar raportat, SAM se poate manifesta în lupusul eritematos sistemic (LES), cu precădere la debutul bolii.

Glucocorticoizii reprezintă principala optiune terapeutică în LES. Unele cazuri necesită corticoterapie în doze mari pentru obţinerea remisiunii (rezistenţa la glucocorticoizi), implicând efecte adverse semnificative.

Prezentare de caz. Un bărbat de etnie romă în vârstă de 28 de ani s-a prezentat în clinica noastră pentru poliartralgii, poliserozită şi fatigabilitate. Pacientul era febril, cu tegumente icterice şi limfadenopatii generalizate. Testele paraclinice au relevat anemie autoimună hemolitică mixtă, leucopenie, hepatocitoliză, creşterea timpilor coagulării, hipertrigliceridemie, sindrom inflamator biologic, hiperferitinemie şi proteinurie persistentă cu pattern nefritic. Evaluările imagistice au evidenţiat revărsat lichidian pleuropericardic, hepatosplenomegalie şi polisinovită. De asemenea, s-au decelat hipocomplementemie şi anticorpi antinucleari, anti-ADN dc şi anti-Sm. Pe piesele bioptice de la nivelul măduvei osoase şi ganglionului limfatic axilar nu s-a remarcat hemofagocitoză. In acest context, s-a diagnosticat SAM asociat LES. Pentru inducţia şi menţinerea remisiunii au fost necesare corticoterapie in doze mari $(6,5 \mathrm{~g}$ de metilprednisolon intravenos, urmate de prednison $1.5 \mathrm{mg} / \mathrm{kgc} / z i$ pentru menţinere) şi pulsuri de ciclofosfamidă.

Concluzii. SAM este o complicaţie severă care trebuie considerată la debutul bolii lupice în context de febră înaltă şi valori serice crescute ale aspartataminotransferazei, lactat dehidrogenazei, proteinei $C$ reactive, feritinei şi 
procalcitoninei. Diagnosticul precoce şi tratamentul prompt ar putea conduce la remisiunea bolii în până la două treimi dintre cazuri.

Rezistenţa la glucocorticoizi impune administrarea unor doze mari de steroizi/agenţi imunosupresori cu efecte adverse potenţial severe. Studiul aprofundat al mecanismelor moleculare ale acestui fenomen este fundamental conceperii unor corticoterapii adecvate.

Correspondence to: Delia Tulbă, MD, Neurology Department, “Colentina” Clinical Hospital,

19-21 Stefan cel Mare street, Sector 2, Bucharest, Romania, Tel.: +40727372537

E-mail: tulba_delia@yahoo.com

\section{REFERENCES}

1. AGGARWAL R, RINGOLD S, KHANNA D, NEOGI T, JOHNSON SR, MILLER A, et al. Distinctions between diagnostic and classification criteria? Arthritis care \& research. 2015; 67(7):891-7.

2. LUIJTEN RK, FRITSCH-STORK RD, BIJLSMA JW, DERKSEN RH. The use of glucocorticoids in systemic lupus erythematosus. After 60 years still more an art than science. Autoimmunity reviews. 2013; 12(5):617-28.

3. PETRI M, ORBAI AM, ALARCON GS, GORDON C, MERRILL JT, FORTIN PR, et al. Derivation and validation of the Systemic Lupus International Collaborating Clinics classification criteria for systemic lupus erythematosus. Arthritis and rheumatism. 2012; 64(8):2677-86.

4. BARCELLINI W. Current treatment strategies in autoimmune hemolytic disorders. Expert review of hematology. 2015; 8(5):681-91.

5. ADAMS PC, BARTON JC. A diagnostic approach to hyperferritinemia with a non-elevated transferrin saturation. Journal of hepatology. 2011; 55(2):453-8.

6. KIM SE, KIM UJ, JANG MO, KANG SJ, JANG HC, JUNG SI, et al. Diagnostic use of serum ferritin levels to differentiate infectious and noninfectious diseases in patients with fever of unknown origin. Disease markers. 2013; 34(3):211-8.

7. GAVAND PE, SERIO I, ARNAUD L, COSTEDOAT-CHALUMEAU N, CARVELLI J, DOSSIER A, et al. Clinical spectrum and therapeutic management of systemic lupus erythematosus-associated macrophage activation syndrome: A study of 103 episodes in 89 adult patients. Autoimmunity reviews. 2017; 16(7):743-9.

8. RIVIERE S, GALICIER L, COPPO P, MARZAC C, AUMONT C, LAMBOTTE O, et al. Reactive hemophagocytic syndrome in adults: a retrospective analysis of 162 patients. The American journal of medicine. 2014; 127(11):1118-25.

9. TAKAHASHI H, TSUBOI H, KURATA I, TAKAHASHI H, INOUE S, EBE H, et al. Predictors of the response to treatment in acute lupus hemophagocytic syndrome. Lupus. 2015; 24(7):659-68.

10. INGAWALE DK, MANDLIK SK, PATEL SS. An emphasis on molecular mechanisms of anti-inflammatory effects and glucocorticoid resistance. Journal of complementary \& integrative medicine. 2015; 12(1):1-13.

11. ZHANG B, SHI Y, LEI TC. Detection of active P-glycoprotein in systemic lupus erythematosus patients with poor disease control. Experimental and therapeutic medicine. 2012; 4(4):705-10.

12. DEJAGER L, VANDEVYVER S, PETTA I, LIBERT C. Dominance of the strongest: inflammatory cytokines versus glucocorticoids. Cytokine \& growth factor reviews. 2014; 25(1):21-33.

Received September $1^{\text {st }}, 2017$ 